\title{
O ADULTÉRIO NA LEGENDA ÁUREA (C. 1270) IMAGEM FEMININA E AFETIVIDADE MARITAL NO FINAL DA ERA GREGORIANA
}

\author{
Néri de Barros Almeida \\ Universidade Estadual de Campinas
}

\begin{abstract}
Resumo
Entre os séculos XI eXIII, a reforma gregoriana procedeu a uma vasta reorganização disciplinar da cristandade. U m de seus desdobramentos mais marcantes aconteceu no âmbito sacramental. A sacramentalização do matrimônio ocupou lugar cuja importância ainda está por ser desvendada pelos estudos relativos à E ra Gregoriana. ${ }^{1}$ Esta sacramentalização tornou mais aguda a necessidade de consideração do problema dos pecados sexuais, em especial, do adultério.
\end{abstract}

\section{Pallavras-chaves:}

Adultério $\bullet$ casamento $\bullet$ reforma gregoriana.

\section{Abstract}

The Gregorian reformation performed a large disciplinary reorganization of the christianity from the XIth to the XIIIth century. One of its most important consequences happened at the sacramental field. The introduction of the matrimony in the sacramental field played a role whose importance is not yet revealed by the studies on the Gregorian Era. This sacramentalization made more pressing the necessity of considering the problem of sexual sin, especially, the problem of adultery.

\section{Keywords}

Adultery $\bullet$ marriage $\bullet$ gregorian reformation.

\footnotetext{
${ }^{1}$ A cronologia da Era Gregoriana varia segundo os autores. Consideramos aqui o período de reformas institucionais romanas que vai de meados do século XI ao terceiro quarto do século XIII, tendo em vista as mudanças no sistema canônico e em suas formas de elaboração e autenticação.
} 
Peter Brown mostrou como, no pensamento tardo-antigo, a sexualidade esteve presente como instância de disciplinamento interior para o exercício da gestão pública de uma ordem instituída. Cedo, a sexualidade se impôs à comunidade cristã como meio de inscrição do cristianismo no espaço público, através do sinal distintivo que o celibato representava sobre o corpo de sua liderança. ${ }^{2}$ Durante a Idade Média, a sexualidade permanece instrumento para este disciplinamento interior e exterior, realizando um modelo pretendido de ordem social. Porém, neste caso, as prescrições rigoristas se generalizaram em escalas diversas pelo conjunto da sociedade, embora sempre tendo, como núcleo, homens da Igreja.

Apenas entre o final do século XI e o final do século XII, quando se dá a estrita proibição do casamento dos padres $^{3}$ e ganha pulso o processo de sacramentalização do casamento, ${ }^{4}$ passa a manifestar-se um ordenamento eclesiástico mais eficiente das práticas sexuais maritais. Dentre os diversos alvos disciplinares da Igreja então, o casamento não pode ser considerado um alvo menor. Ao pretender disciplinar a sexualidade transgressora extra-marital, por exemplo, a Igreja tocava num problema antigo e difícil, a tradição de desigualdade dos gêneros face à punição das práticas sexuais transgressoras, notadamente o adultério - situação experimentada à revelia das prescrições neo-testamentárias ${ }^{5}$

\footnotetext{
${ }^{2}$ BROWN, P. Corpo e sociedade. O homem, a mulher e a renúncia sexual no início do cristianismo. Rio de Janeiro: Jorge Zahar, 1990.

3“A situação mais freqüente em matéria de castidade é, no entanto, muito simplesmente, o casamento dos padres. Os concílios e outras prescrições dos séculos VI e VII foram, durante muito tempo, inoperantes: casar-se é para um padre coisa normal e corrente. No século VIII, as episcopissae (mulheres de bispos), presbiteriae (mulheres de padres) etc. governam a vida interior de seus maridos e são honradas. Nos séculos IX e X, os membros do clero deixaram de casar, obrigados a isso pela legislação, a partir de então severamente aplicada - devem separar-se das esposas -, mas passaram do casamento ao concubinato, situação então perfeitamente tolerada, quando estável e monogâmica... No entanto, esta situação não dura muito. São exercidas múltiplas pressões nos curas para os obrigar a mudar; a dos eremitas inspirados, a da arraia miúda dos campos (influenciada pelos eremitas, 1020-1030), a dos mosteiros locais que superintendem certas paróquias (9501050) e, finalmente, a dos bispos (1050-1150). A partir de 1030, o clero começa a reagrupar-se nas aldeias fortificadas onde forma comunidades (colegiadas) que servem também as modestas capelas rurais; no século XII, a vida comum torna-se a forma normal da vida clerical. A evolução concluiu-se em 1150". BERNOS, M. et alii. O fruto proibido. Lisboa: Ed. 70, s\d, p. 100 e 127. ${ }^{4} \mathrm{Um}$ dos referenciais cronológicos relevantes desta história foi a incorporação do matrimônio na lista dos sacramentos pelo papa Luciano III em 1184.

${ }^{5}$ Diversas passagens do Novo Testamento insistem na condenação do adultério tanto masculino quanto feminino (Mateus 5:31-32 e 19:9, Marcos 10: 11-12, Lucas 16:18, João 8: 3-11, Romanos 7:2-3 e I Coríntios 7:10-11;39).
} 
e dos esforços da própria Igreja. Atuar contrariamente a esta desigualdade "naturalizada" pelas práticas sociais significava alterar uma esfera fundamental do poder familiar e masculino. O problema do adultério permite, assim, acompanhar as oscilações que caracterizaram as relações entre a autoridade eclesiástica e o poder público em esferas diversas de sua manifestação.

Até o século XII, a igualdade dos seres humanos no pecado não havia chegado a ameaçar a desigualdade entre os sexos na culpabilização por delitos sexuais. A despeito da culpa universal e da salvação comum, o próprio clero, sobretudo monástico, reforçou a imagem da mulher como ser que induz ao pecado sexual. Por outro lado, a Idade Média herdou da Antigüidade e aperfeiçoou com sua espiritualização e moralização das práticas sexuais, notadamente do casamento, certa aproximação jurídica entre adultério e prostituição. Segundo a Lex Julia Adulteriis (18 d.c.), a conjux ingênua ou claríssima poderia se subtrair das penas por adultério apresentando-se à Justiça como prostituta. Sob Teodósio (346-395), os culpados de adultério eram conduzidos publicamente a um lugar de prostituição. A lei romana também definia a prostituição de forma bastante ampla como sendo a prática de uma pessoa que concedia favores sexuais livremente, sem a especificação de qualquer recebimento para tal. ${ }^{6}$

Podemos observar confusões semelhantes na Legenda Aurea, ${ }^{7}$ coletânea hagiográfica composta pelo teólogo dominicano e futuro bispo de Gênova, Jacopo da Varazze. Nesta obra, o termo prostituição pode aplicar-se genericamente aos pecados sexuais femininos. Mulheres como santa Teodora, cujo pecado é o adultério, podem também aparecer qualificadas como prostitutas. A legenda de santa Maria Madalena mostra, com clareza, de que forma o perfil da mulher luxuriosa, de vida sexual e social independente, se confunde com o da prostituta. Apenas as legendas de santa Maria Egipcíaca ${ }^{8}$ e de santa Taís ${ }^{9}$ deixam

\footnotetext{
${ }^{6}$ VACANDART, E. Adultère. Diccionnaire d'archeologie e de liturgie chretienne, p. 547-549 e BRUNDAGE, J. A. Law, sex and christian society in medieval Europe. ChicagolLondon: University of Chicago Press, 1987, p. 30 e 44. SCHMITT-PANTEL, P. L'âne, l'adultère et la citè. In: LE GOFF, J. e SCMITT, J. C. (orgs.). Le charivari. Paris\New York: Mouton $\backslash$ La Haue, 1981, p. 120, constata, nos julgamentos públicos contra réus de adultério de cidades antigas gregas, a identificação tanto do homem como da mulher com a figura da prostituta.

${ }^{7}$ JACOPO DA VARAZZE. Legenda Aurea. Giovanni Paolo Maggioni (ed.). Firenze: Sismel/ Edizioni del Galluzzo, 1999. Todas as legendas mencionadas em nosso texto foram extraídas da edição Maggioni. Dessa forma, as citações de legendas que se seguem acompanham a numeração e a paginação estabelecidas pelo editor italiano.

${ }^{8}$ De Sancta Maria Egyptiaca, LIV, p. 374-377.

${ }^{9}$ De Sancta Thaysi, CXLVIII, p. 1038-1040.
} 
claro o recebimento de pagamento pelo uso do corpo destas santas pecadoras. À época de Jacopo da Varazze, as mudanças sociais e econômicas cada vez mais levavam à superação da concepção moralizante da prostituta em favor de sua identificação como a mulher semi-confinada aos lupanares - que proliferam nas cidades de então - que vende seu corpo. A despeito da importância desse contexto para o estabelecimento de uma identidade estrita da atividade das prostitutas - passo significativo para uma melhor definição e enquadramento jurídico dos pecados femininos $-{ }^{10}$ de modo geral, a prostituição na Legenda Aurea ainda diz respeito à moralidade e não ao comércio.

Pela via de heranças várias, acolhidas, ordenadas e promovidas pelos ambientes monásticos, a desigualdade entre homens e mulheres face ao adultério cristalizou-se a ponto deste tornar-se um pecado feminino por excelência. A Lex Julia Adulteriis foi um dos legados antigos à desigualdade entre homens e mulheres adúlteros. De acordo com ela, os homens podiam ter relações extramaritais com concubinas e prostitutas sem se tornarem alvo de penalidades. Era-lhes vedado, no entanto, o intercurso extra-marital com mulheres da aristocracia. ${ }^{11}$ Os juristas romanos pré-cristãos entendiam o adultério como um crime da mulher casada que tinha relações sexuais com qualquer um que não fosse seu marido. No entanto, a inexistência de vínculos legais nas ligações entre escravos e entre homens livres e suas concubinas impedia estas mulheres de serem submetidas a julgamento por adultério. ${ }^{12}$

A tradição judaica impulsionara as práticas no mesmo sentido. Nela, embora o casal adúltero devesse ser punido igualmente com a morte, ${ }^{13}$ a esposa estava impossibilitada de mover ação de adultério contra seu marido. ${ }^{14}$ Neste segundo caso, a valorização da castidade feminina - não apenas das mulheres casadas, como também das viúvas e mulheres solteiras - decorria de imperativos de pu-

\footnotetext{
${ }^{10}$ KARRAS, R. M. Holy harlots: prostitutes saints in medieval legend. Journal of the History of Sexuality, 1, 1990, p. 8-11.

${ }^{11}$ Segundo SIVAN, H. Le corps d'une pécheresse, le prix de la piété. La politique de l'adultère dans l'Atiquité tardive. Annales HSS, 2, 1998, p. 234, o termo legal adulter, quando aplicado a um homem, diz respeito, na Roma antiga, aos "amantes celibatários de mulheres casadas, por definição, um homem casado que tinha uma ligação extra-marital não era um adulter”. Em cidades gregas, o adultério masculino era configurado apenas quando se tratava de relações extra-maritais com a mulher de outro cidadão. A união com mulheres - casadas ou solteiras - de outra condição social não configurava adultério do cidadão casado (SCHMITT-PANTEL, P., op. cit., p. 120-121).

${ }^{12}$ BRUNDAGE, J. A., op. cit., p. 30-32.

${ }^{13}$ Levíticos 20:10 e Deuteronômio 22:22.

${ }^{14}$ VACANDART, E., op. cit., p. 546-547.
} 
reza religiosa, artifício utilizado face ao perigo de absorção pelas comunidades circundantes. ${ }^{15}$ Nas leis germânicas, temos igualmente a feminilização do crime de adultério, costumeiramente tratado como matéria doméstica. Poucos códigos germânicos previam a penalização do adultério masculino. ${ }^{16}$ As prescrições paulinas e as mudanças jurídicas ocorridas na época de Constantino, favoráveis à equiparação dos gêneros face ao adultério, ${ }^{17}$ foram ineficazes para mudar o peso dessas heranças sobre as práticas cristãs.

Desde as primeiras regulamentações canônicas dos pecados sexuais, homens e mulheres estiveram sujeitos às mesmas penas por adultério; além disso, buscou-se estimular a denúncia feminina dos crimes sexuais de seus esposos aos padres. No entanto, o adultério continuou sendo uma prática que adquiria significado social maior quando considerada do lado feminino. Assim, durante boa parte da Idade Média, vemos uma preocupação desigual com a punição dos desregramentos sexuais. A essencialidade das trocas matrimoniais, como veículo de estabelecimento de pactos de poder no período, reforçou a imagem da sexualidade como foco de controle da feminilidade, situação que fazia do repúdio uma prática corrente e unilateral da aristocracia. A despeito da censura bíblica ao repúdio, por outras razões que não a prostituição, ${ }^{18}$ este vigorou firmemente durante boa parte da Idade Média. Apenas a partir da Idade Média central, podemos constatar, nas prescrições canônicas, um avanço na equiparação de homens e mulheres no casamento, fato que se torna perceptível na importância dada pelo Decreto (Concordia Discordantium Canonum) de Graciano (1140) ao débito conjugal e no estabelecimento do consentimento mútuo como elemento fundamental para a efetivação da união matrimonial, com Inocêncio III. Esta tentativa de equiparação entre os sexos teria inevitável repercussão na forma como eram até então encarados, na prática, os pecados sexuais femininos e masculinos. Complexa pela própria amplitude secular da matéria que a compõe, a Legenda Aurea ordenada por Jacopo da Varazze não se furta ao contexto em que antigos princípios cristãos - como o da igualdade dos seres humanos frente ao pecado - adquirem projeção nova em uma Igreja

\footnotetext{
${ }^{15}$ JAEGER, N. Il diritto nella Bibbia. Giustizia individuale e sociale nell'Antico e nel Nuovo Testamento. Assisi: Edizioni pro civitate christiana, 1960, p. 116-117.

${ }^{16}$ BRUNDAGE, J. A., op. cit., p. 132-133.

${ }^{17}$ PILOSU, M. A mulher, a luxúria e a Igreja na Idade Média. Lisboa: Estampa, 1995, p. 168.

${ }^{18}$ Mateus 19:7-9.
} 
papal que se lançara, desde meados do século XI, numa investida ideológica de envergadura social mais ampla e arriscada.

Jacopo da Varazze não formaliza um discurso exortativo sobre o adultério na Legenda Aurea. O problema aparece em sua narrativa atrelado a situações de múltiplo interesse. No conjunto, porém, este aparecimento difuso do adultério não deixa de revelar um posicionamento sobre a questão que é comum a todo o texto. Situações adulterinas e menções ao termo "adultério" e seus correlatos aparecem na Legenda Aurea ao longo de quatorze das cento e setenta e seis legendas que podem ser atribuídas a Jacopo da Varazze. Apenas em nove dessas legendas o adultério - efetivo ou presumido - integra o desencadeamento dos acontecimentos, embora não constitua o alvo central da narrativa. Esta última é sempre voltada para a defesa da excelência da castidade e da eficácia da penitência à qual aparecem sempre submetidos primeiramente os "grandes". Os episódios dizem respeito a adultérios da realeza e da aristocracia - em que estão incluídos os santos e seus familiares - de infiéis (muçulmanos) e hereges (arianos) de alta extração social. Assim, o tema do adultério consolida um texto interno à obra de Jacopo da Varazze, dirigido contra os focos de indisciplina na aristocracia, aos quais contrapõe um quadro idealizado de relações, submetido estritamente à autoridade pública do clero. Os relatos podem ser classificados em quatro grupos:

\section{Adultérios da realeza, efetivos ou presumidos}

1.1 Legenda de são Lourenço: ${ }^{19}$ o imperador Henrique II (973-1024), que fizera voto de castidade com sua esposa, futura santa Cunegunda, instigado pelo diabo, suspeita que esta o trai com um soldado. Submete-a injuriosamente ao ordálio durante o qual lhe bate no queixo indignado diante de sua alegação de inocência. Quando da morte do imperador, estes atos pesam negativamente na balança que mede seus atos. Henrique II é resgatado dos demônios por são Lourenço que coloca na balança uma urna de ouro que o imperador doara à igreja de Eischstat, consagrada ao santo.

1.2. Legenda de são Pelágio: ${ }^{20}$ no relato imediatamente anterior à conversão ao catolicismo do rei lombardo Adaloardo, casado com uma piedosa cristã, Jacopo da Varazze conta como um outro rei lombardo, Albuíno (?-573),

\footnotetext{
${ }^{19}$ De Sancto Laurentio Martyre, CXIII, p. 764-765.

${ }^{20}$ De Sancto Pelagio Papa, CLXXVII, p. 1259-1260.
} 
depois de matar o rei dos gépidas e desposar sua filha Rosamunda, obrigou-a a beber em uma taça feita com o crânio de seu pai instigando-a jocosamente com a frase: "bebe com teu pai". Movida por um ódio violento, Rosamunda se instala secretamente no leito da amante de um dos comandantes de Abuíno. Ao revelar quem era, utiliza a traição involuntária do comandante para levá-lo a dar morte ao rei. O oficial, pressionado, encomenda o assassinato no qual a rainha colabora dificultando o acesso do rei às armas colocadas próximas a sua cama. Rosamunda foge para Ravena com o comandante que leva consigo o tesouro do palácio. Lá, ela se enamora pelo prefeito da cidade e decide então matar o oficial. Este, percebendo-se envenenado, obriga-a a beber da mesma poção.

1.3. Legenda de são Pelágio: ${ }^{21}$ a mulher de Oto III (980-1002), enamorada por um conde, deseja "prostituir-se" com ele. Ao ser rejeitada, difama o conde junto ao imperador que o condena a morte sem ouvi-lo. Posteriormente, a condessa, cumprindo uma promessa feita ao marido, acusa o imperador de morte injusta e oferece-se para prová-lo por meio do ordálio. O pontífice e os próceres se opõem ao ordálio dando tempo para que o imperador examine com cuidado a denúncia que fora feita pela rainha. Como resultado, a calúnia é confirmada. A rainha é condenada a ser queimada viva na fogueira e a viúva recebe quatro castelos do imperador.

1.4. Legenda da decapitação de são João Batista: ${ }^{22}$ narra como Herodes, a caminho de Roma, passa pela casa de seu irmão Filipe e combina secretamente com sua cunhada Herodias repudiar sua mulher e depois casar-se com ela, contrariando a lei judaica segundo a qual não se deve desposar a esposa do irmão enquanto este vive. ${ }^{23}$ A mulher de Herodes, filha do rei Aretas de Damasco, ao saber deste plano, volta para sua terra natal. Da situação resulta a inimizade deste rei para com Herodes. A legenda desenvolve o episódio bíblico do adultério e incesto de Herodes e Herodias, valorizando a culpa desta na decapitação de são João. Quando o ocioso Herodes cai em desgraça, após humilhar a Herodes Antipas, este irmão de Herodias manifesta-se para acolhê-la. Esta, porém, prefere seguir também na adversidade ao marido

\footnotetext{
${ }^{21}$ Idem, p. 1275.

${ }^{22}$ De decollatione Sancti Iohannis Baptiste, CXXI, p. 874-875.

${ }^{23}$ Levíticos 20:21.
} 
que acompanhara na prosperidade. Assim, parte com Herodes para o exílio em Lyon, onde os dois morrem depois de viverem miseravelmente.

\section{Santos que têm esposas e mãe envolvidas em falsos casos de adultério}

2.1. Legenda de santo Eustáquio: ${ }^{24}$ santo Eustáquio, originalmente chamado Plácido, comandante militar do imperador Trajano, juntamente com sua esposa, destacava-se no exercício da misericórdia, embora fosse pagão. Por isso, durante uma caçada ao cervo, recebe do próprio Cristo exortação para tornar-se cristão com sua família. De volta à sua casa, no leito, revela à esposa a visão que tivera e ouve dela um relato equivalente. Ambos são batizados juntamente com seus dois filhos pelo bispo de Roma e recebem os nomes de Eustáquio, Teopista, Agapito e Teopisto. Depois disso, Eustáquio tem outra visão em que o futuro lhe é revelado. Numa trajetória semelhante à de Jó, Eustáquio terá de, através de tentações, se submeter à humildade para, finalmente, depois de provada sua paciência, voltar a ser exaltado. Depois de perder tudo, Eustáquio parte com a família em um navio. Lá, o comandante, movido pelo desejo pela bela Teopista, obriga o santo a fugir com os filhos. Na fuga, Eustáquio tem os filhos levados por feras e lamenta por ter tido a mulher raptada (ablata). Depois de muitas reviravoltas que permitem que sua mulher não seja tocada pelo comandante e que seus filhos sejam salvos, seguidas coincidências revelam a origem de cada um dos membros da família, promovendo sua reunião e o restabelecimento de sua posição social. Logo depois, morto Trajano, Adriano os obriga a sacrificar. Diante de sua recusa, a família é submetida ao martírio.

2.2. Legenda de são Clemente: ${ }^{25}$ legenda com enredo semelhante ao da anterior que narra a conversão do santo, de seus pais e de seus dois irmãos. A conversão é promovida à custa da prova da superioridade da providência divina face aos engodos e limitações da filosofia, da magia e da astrologia. Ainda na infância, o santo, futuro sucessor de são Pedro, tem sua família dispersa quando sua bela mãe, Macidiana, é obrigada a fugir do assédio de seu cunhado. O pai de Clemente que, a partir do que lhe contara seu próprio irmão, passara a vida acreditando que sua esposa tivesse fugido

\footnotetext{
${ }^{24}$ De Sancto Eustachio, CLVII, p. 1090-1098.

${ }^{25}$ De Sancto Clemente, CLVI, p. 1188-1195.
} 
por amor a um escravo, defende a inocência de Macidiana, uma vez que o adultério da mesma teria sido determinado pelo contexto astrológico de seu nascimento. À predestinação e inimputabilidade dos crimes, defendidas pelo pai de Clemente, são Pedro contrapõe o fato da preservação da vida e castidade de Macidiana. Assim, depois de anos de separação e sofrimentos, são Pedro reúne novamente a família do santo.

2.3. Legenda de são Juliano: ${ }^{26}$ Juliano, ainda jovem, sabendo, por meio da profecia que ouve de um cervo durante uma caçada que seria o responsável pela morte dos pais, foge de casa. Anos depois, já casado, sua esposa recebe um casal que identifica como seus sogros, aos quais, por hospitalidade, oferece seu leito conjugal. Chegando em casa, o santo se depara com o casal adormecido. Julgando tratar-se de sua esposa e um amante em adultério, aproxima-se silenciosamente de ambos e os mata com a espada. O esclarecimento da situação leva o santo para uma vida de caridade, penitência e trabalho, na qual é seguido voluntariamente por sua esposa. Esta o chama a partir de então de "irmão" e passa a compartilhar de sua dor. Certo dia, o santo encontra um leproso à morte e o coloca em seu próprio leito. $\mathrm{O}$ doente então se transforma em um ser vivificado e revela que a penitência de Juliano fora aceita e que logo ele e sua esposa repousariam no Senhor.

\section{Adultérios efetivo e presumido de santos}

3.1. Legenda de santa Teodora: ${ }^{27}$ invejoso da santidade de Teodora, mulher casada de Alexandria, o diabo desperta em certo homem desejo por ela. Este lança mão de todos os recursos para conquistá-la. Enfim, por intermédio de uma feiticeira que convence Teodora de que Deus não via o que se passava após o pôr-do-sol, esta aceita recebê-lo durante a noite. Logo depois, Teodora procura uma monja que a alerta de seu erro. Movida pelo arrependimento, Teodora abandona secretamente sua casa, veste-se de homem e ingressa em um mosteiro masculino. Aí é acusada de engravidar uma moça, sendo expulsa da comunidade com a criança cuja paternidade lhe é atribuída. Depois de passar por inúmeras tentações - durante as quais o diabo a chama indistintamente de "prostituta" e "adúltera" - e de realizar milagres, Teodora

\footnotetext{
${ }^{26}$ De Santo Iuliano, XXX, p. 209-217.

${ }^{27}$ De Sancta Theodora, LXXXVIII, p. 611-615.
} 
é reincorporada à comunidade monástica. Decorrido pouco tempo, a santa morre, vindo à tona o segredo de sua sexualidade. Providencialmente, o marido é avisado de sua morte. Depois de reencontrar a esposa, ele decide passar o resto de seus dias no mosteiro, vindo a ocupar a mesma cela que fora de Teodora e dando continuidade à educação de seu filho adotivo. Este, depois de adulto, torna-se abade do mesmo mosteiro.

3.2. Legenda de santa Margarida: ${ }^{28}$ casada, Margarida abandona o marido na noite de núpcias e, depois de cortar os cabelos e vestir roupas masculinas, ingressa em um mosteiro com o nome de Pelágio. Por sua retidão, Pelágio é escolhido provisor do mosteiro feminino. Nele, uma monja, que era mensageira do lugar e que, incitada pelo diabo, cometera adultério, o acusa de ser o adúltero que a engravidara. A morte de Pelágio revela a verdade.

\section{Menções ao adultério fora do contexto de sua realização ou presunção objetiva}

4.1. Legenda de uma virgem de Antioquia: ${ }^{29}$ narrativa baseada em santo Ambrósio que argumenta longamente em defesa da fé e da castidade face ao adultério e à prostituição que aparecem equiparados na legenda. Abordada para que aceitasse um pretendente, a bela santa se nega. Seus perseguidores pressionam-na para que escolha entre a fé no Deus cristão e a castidade, o que dá lugar às considerações da santa de que, escolhendo negar sua fé, se manteria virgem, porém, se tornaria adúltera. A santa conclui pela superioridade da declaração de fé frente à pureza do corpo, lembrando das figuras veterotestamentárias de Raabe, a prostituta que encontrou a salvação ao ajudar os servos do Senhor e de Judite que, pelo bem de seu povo, preparouse para seduzir um adúltero sem ser por isso tomada como adúltera. Por milagre, a virgem é salva do lupanar por um soldado que troca de roupas com ela. Com a fuga da santa, os homens que entram adúlteros no lupanar saem dele castos. Assim, segundo o texto, vencendo seu próprio sexo, a virgem preferiu se tornar mártir a adúltera e entregou-se aos carrascos.

4.2. Legenda de são Lourenço: ${ }^{30}$ baseado em João Beleth, Jacopo da Varazze explica a mudança das vigílias em jejuns devido às desordens - dentre as

\footnotetext{
${ }^{28}$ De Sancta Margarita dicta Pelagio, CXLVII, p. 1036-1037.

${ }^{29}$ De virgine quadam antiochena, LX, p. 415-420.

${ }^{30}$ De Sancto Laurentio martyre, CXIII, p. 773.
} 
quais o adultério - que aconteciam à noite no interior dos templos quando os cristãos para lá se dirigiam com suas esposas e filhas.

4.3. Legenda de são Paulo: ${ }^{31}$ durante sua passagem por Mitilene o apóstolo foi picado na mão por uma víbora. Conta-se que, a partir de então, o hospedeiro do santo e seus descendentes passaram a não mais padecerem com os ataques dos animais venenosos. Estes, então, passaram a colocar víboras junto aos filhos recém-nascidos de suas esposas a fim de verificar se eram legítimos.

4.4. Legenda de são Paulo: ${ }^{32}$ menção aos efeitos da passagem e da pregação de Paulo pelas localidades: desaparecimento dos tiranos, das armadilhas dos falsos irmãos, dos adúlteros, dos ladrões, dos homicidas; como o sol em relação às trevas, diante de sua presença a verdade renascia e o adultério e outras abominações desapareciam.

4.5. Legenda de são Pelágio: $:^{33}$ referindo-se aos costumes dos muçulmanos, destaca que estes podem ter quatro mulheres legítimas e repudiar e retomar cada uma até três vezes e que podem ter quantas escravas quiserem e vendê-las a menos que estejam grávidas deles. Podem tomar esposas em sua própria família, o que é considerado positivo, uma vez que aprofunda seus laços de amizade. Entre os muçulmanos, os adúlteros são apedrejados e os fornicadores condenados a oitenta açoites. Maomé pretendia que lhe tinha sido permitido por Deus aproximar-se das mulheres dos outros, a fim de gerar homens virtuosos e profetas. Um de seus escravos proibira a mulher de falar com o Profeta e, ao vê-la fazendo-o, imediatamente a repudiou. Por causa disso, Maomé, temendo a reação do povo, produziu um documento que disse trazido do céu em que se dizia que a mulher repudiada seria daquele que a recolhesse.

4.6. Legenda de santo Ambrósio: ${ }^{34}$ relato da Historia tripartite dá conta de que santo Ambrósio de Milão compara o assassínio de cinco mil pessoas ordenado pelo imperador Teodósio como reprimenda contra a morte de alguns juízes de Tessalônica sem a averiguação dos reais responsáveis,

\footnotetext{
${ }^{31}$ De Santo Paulo apostolo, LXXXV, p. 577.

${ }^{32}$ Idem, p. 593.

${ }^{33}$ De Sancto Pelagio papa, CLXXVII, p. 1265.

${ }^{34}$ De Sancto Ambrosio, LV, p. 389.
} 
ao adultério e homicídio cometidos por Davi. Em seguida o imperador se submete à penitência pública e à limitação de sua participação nos ofícios aos lugares devidos aos demais fiéis.

4.7. Legenda de são Mateus: ${ }^{35}$ novamente o adultério e o homicídio cometidos por Davi são lembrados no tratamento do tema da penitência e de seu poder transformador que teria feito do rei pecador, profeta e salmista.

4.8. Legenda dos santos Barlaão e Josafá: ${ }^{36}$ são Barlaão, acusado de induzir o filho de um rei ao erro, enumera os erros e abominações na adoração aos deuses, entre eles o adultério de Vênus, ora com Marte, ora com Adônis, e as transformações de Júpiter em animal para cometer adultério.

4.9. Legenda de são Vicente: ${ }^{37}$ o juiz Daciano, diante da resistência do santo aos suplícios que lhe eram infringidos, ataca os carrascos, lembrando sua eficácia anterior em obter tudo de adúlteros e parricidas mediante tortura.

Numa observação de conjunto, a mulher na Legenda Aurea parece muito próxima da visão que dela transmitiram os padres do deserto. Fosse ela pecadora ou não, o caráter vicioso da natureza feminina é um dos marcos de sua consideração na obra do dominicano Jacopo da Varazze. A sexualidade é o princípio ativo da teia de pecados femininos. Sua beleza inspira a luxúria de outros e a sua própria, como na vida de santa Maria Madalena. ${ }^{38}$ Por isso, convertidas, as santas pecadoras se travestem e ingressam em comunidades religiosas masculinas, ${ }^{39}$ ou então, penitentes, se desfiguram no ascetismo ${ }^{40}$ até não poderem mais ser identificadas como mulheres. A penitência eficaz do pecado dessas santas só pode ser atingida mediante o rompimento da tutela masculina tradicional de pais, maridos e irmãos e com sua submissão à tutela divina e difusa do parentesco espiritual. Dessa forma, o desejo de santificação feminina revela-se um meio veemente de requisição de autonomia física, espiritual e social. Funciona,

\footnotetext{
${ }^{35}$ De Sancto Matheo, CXXXVI, p. 962-963.

${ }^{36}$ De Sanctis Barlaam et Iosaphat, CLXXVI, p. 1250.

${ }^{37}$ De Sancto Vincentio, XXV, p. 175.

${ }^{38}$ De Sancta Maria Magdalena, XCII, p. 628-642.

${ }^{39}$ De Sancta Marina Virgine, LXXIX, p. 534-535; De Sancta Margarita dicta Pelagius, CXLVII, p. 1036-1037; Sancta Theodora, LXXXVIII, p. 610-615.

${ }^{40}$ De Sancta Pelagia, CXLVI, p. 1033-1035 e De Sancta Maria Egyptiaca, LIV, p. 374-377.
} 
assim, como um contraponto à sexualidade desregrada como única opção de manifestação da vontade feminina, como acontece com as rainhas adúlteras. No entanto, esse apelo não deixa de fazer-se através da negação da feminilidade. Penitenciando-se de sua vida de prostituição, santa Taís ${ }^{41}$ encerra-se em uma minúscula cela, onde se confunde com os excrementos que se avolumam junto a seu corpo por anos. Fora da tutela masculina que assegura, pelo controle da castidade das mulheres, o prestígio e solidez das trocas políticas, essas santas são concebidas, pelos escritos masculinizados da Idade Média, como dominadoras e críticas privilegiadas de sua sexualidade.

A natureza sexual da mulher torna-a sempre responsável pelo conluio sexual desregrado e, portanto, pelos pecados sexuais de seus parceiros. No caso do adultério e incesto de Herodes, o narrador, seguindo João Crisóstomo, é enfático ao ressaltar as responsabilidades de Herodias. Sua condição de homicida complementa de forma pouco surpreendente a face monstruosa da adúltera. Enquanto os homens são sexualmente tentados, as mulheres são potencialmente tentadoras. As legendas de santa Pelágia ${ }^{42}$ de santa Taís e de santa Maria Madalena igualmente associam a seu perfil a avidez pelas riquezas e sua exibição. Assim, ao menos parte do tratamento da figura feminina coloca-se, primeiramente, como uma mensagem destinada à moralização das mulheres e à temerização dos homens.

A herança monástica fala alto nessa visão da feminilidade, mas a ela se sobrepõem outros níveis de leitura, não apenas em razão da natureza heterogênea da tradição cristã, mas também pela atualização que o contexto impõe à leitura da mesma. Santas pecadoras e virgens se irmanam na vitória que obtêm sobre o próprio sexo quando se masculinizam. Este princípio monástico de que a possibilidade de libertação do sexo existe dentro do masculino, no entanto, se circunscreve ao masculino submetido aos votos religiosos. Dessa maneira, as legendas associam, embora timidamente, os homens às faltas sexuais femininas, uma vez que é preciso fugir de si e fugir deles para fugir ao sexo. Assim, não podemos considerar o texto de Jacopo da Varazze como mera repetição de modelos antigos. Dominicano de prestígio político e teológico que lhe valeram a condição de arcebispo de Gênova, Jacopo da Varazze não era inconsciente dos propósitos inovadores da Igreja de seu tempo. Já no final do século XII,

\footnotetext{
${ }^{41}$ De Sancta Thaysi, CXLVIII, p. 1038-1040.

${ }^{42}$ De Sancta Pelagia, CXLVI, p. 1033-1035.
} 
acontece um movimento que pretende promover a reabilitação das prostitutas que tem um de seus expoentes em Inocêncio III (1198-1216). A despeito da oposição doutrinária, este papa teve importante papel na exortação sobre a importância da conversão das prostitutas, chegando a prometer a remissão dos pecados àqueles que com elas se casassem. ${ }^{43}$

A mesma reabilitação foi proposta de forma mais sutil para as adúlteras que também passaram, ao menos do ponto de vista canônico, a serem vistas como equivalentes a seus parceiros, face aos pecados sexuais. Essa atitude retomava antigas posições cristãs nunca implementadas de maneira plena. Já no século VI, acentuaram-se as investidas da Igreja para retirar da esfera doméstica o julgamento das causas sexuais, como o adultério. Estas práticas passaram a ser alvo de penalidades canônicas que, em caso da publicidade do adultério, resultavam em penas públicas de humilhação e penitência. $\mathrm{O}$ adultério era encarado mais como uma falha moral que como crime público, o que reservava, aos ofensores, remédios espirituais em vez da execução pública e da violência familiar, marital e paterna. Mediante a penitência, esperava-se que o marido retomasse a esposa adúltera. Recusar-se a fazê-lo constituía pecado. Na prática, porém, a legislação imperial atesta a perseverança do antigo costume que admitia ao marido o direito de matar a esposa adúltera. A Novela 117 de Justiniano tenta propor, como opção ao marido, o direito de confinar a esposa em um convento pelo período de dois anos, ao final do qual poderia, ou não, retomá-la. Este segundo caso obrigava a mulher a passar o resto de seus dias na clausura. Neste mesmo código, o homem que cometesse adultério estava sujeito a penalidades mais suaves, embora já fosse visto como transgressor. Este perdia o direito de dispor de propriedades e dotes nupciais e fornecia à esposa o direito de mover ação de divórcio contra ele.

Entre 1140 e 1234, a lei canônica, de rudimentar e confusa, torna-se um sistema legal mais complexo e eficiente. A Igreja consegue, então, impor a quase unanimidade em torno da competência de suas cortes e juízes para lidar com questões de separação, divórcio e validade dos casamentos. Naquele momento, pela primeira vez, canonistas e legisladores tentaram impor penalidades criminais à fornicação bem como ao adultério. Fazem-no recuperando antigas atribuições requisitadas pelo poder imperial. Passava-se a coibir o assassinato da esposa adúltera, a custo da imputação de sua morte ao marido, e previa-se a privação

${ }^{43}$ PILOSU, M., op. cit., p. 94. 
da respeitabilidade pública (infâmia) e do direito jurídico de testemunhar, aos acusados de ofensas sexuais (adultério, bigamia, rapto, prostituição, alcoviteirismo, sexo com não cristãos, relações homossexuais, bestialidade e masturbação).

A despeito disso, as implicações do adultério não eram as mesmas para homens e mulheres. Na prática, esperava-se que o marido expulsasse sua esposa, sob o risco de incorrer em impiedade. A esposa, por sua vez, se era desonrada pelo adultério do marido, não tinha seu direito ao divórcio admitido. Nesta matéria, a lei civil se desenvolverá firmemente atrelada às prescrições canônicas. ${ }^{44}$ As penas para casos de adultério previam a deposição dos clérigos, a excomunhão dos leigos, a imposição de humilhações públicas (vestir roupas rasgadas, ter a cabeça raspada, receber chibatadas do poder civil), penitências (quarenta dias de jejum por sete anos consecutivos), a expulsão da esposa pelo marido que poderia reter seu dote. A persistência no erro poderia levar à perda do direito à comunhão até a morte do companheiro legítimo. A parte inocente do casal poderia, por sua vez, internar-se em um mosteiro, sem o consentimento do cônjuge. No entanto, em casos em que o adultério não se tornasse de conhecimento comum, priorizava-se a comutação das penas públicas em penitências discretas que não expusessem a transgressão. ${ }^{45}$

A discrição eclesiástica, face ao conteúdo da confissão recomendada pelo IV Concílio de Latrão, resulta na proteção à mulher adúltera e, conseqüentemente, numa tendência à equiparação dos gêneros frente aos delitos sexuais. $\mathrm{O}$ novo conceito de confissão que aparece em 1215 insiste no “... segredo acerca do pecado relativamente a terceiros, especialmente nas instituições como os conventos e no seio do matrimônio". ${ }^{46} \mathrm{O}$ discurso pastoral de Jacopo da Varazze acompanha implicitamente este processo. Um primeiro sinal disso aparece no quadro que delineia as culpas adulterinas. Nele, a mulher não é a única responsável pelos casos de adultério. Ao lado dos desejos e pecados femininos, o adultério e seus escândalos surgem movidos pela desconfiança de maridos e reis injustos que caluniam suas esposas ou se dobram aos caluniadores que investem contra a integridade do matrimônio. A vida de Teodora, única santa adúltera da Legenda Áurea, detalha este quadro de tentativa de partilha, entre os sexos, da culpa por delitos sexuais.

\footnotetext{
${ }^{44}$ A partir dos séculos XII-XIII crescem os esforços das autoridades públicas laicas no sentido de estender sua jurisdição sobre as atividades sexuais consideradas ilícitas.

${ }^{45}$ BRUNDAGE, J. A. op. cit., 1987, p. 3, 59, 68, 119, 207, 307, 389, 482.

${ }^{46}$ PILOSU, M. op. cit., Lisboa: Estampa, 1995, p. 102-103.
} 
As santas mártires da Legenda Aurea têm uma surpreendente similaridade de caráter com seus colegas santos. São moralmente inabaláveis, resolutas, oradoras intelectualmente brilhantes e destemidas. Aproximam-se dos santos também pela recusa à sexualidade. O repúdio a toda iniciativa amorosa se soma à masculinização de suas atitudes, representação da santidade feminina que encontra seu clímax na vida das santas travestidas em monge. Pertencente a esse grupo, a vida de santa Teodora, porém, parece vencer distâncias do fosso que existe entre o universo sexualizado das mulheres e as vítimas masculinas da condição feminina. Seu pecado não evoca um rompimento completo com seu companheiro. A narrativa da história de sua vida de dedicação religiosa é pontuada pela lembrança que ela e seu marido têm um do outro. A ligação entre eles não é desfeita, seja pelo adultério ou pela vida religiosa, o que se confirma quando o marido substitui Teodora em sua cela e dá prosseguimento à educação do menino que ela criava como filho.

A vida de Teodora não fala de mulheres e homens separadamente, mas do casal. Nesse caso, podemos observar uma das razões da pequena atenção dada por Jacopo da Varazze ao adultério. Seu discurso se concentra na natureza e solidez das relações entre marido e esposa que supera a existência do pecado. A legenda de Santa Teodora pode, dessa forma, apresentar uma visão mais condescendente da mulher. No entanto, esta só se dá na medida em que o enfoque deixa de ser o da sexualidade. Assim, a ligação entre Teodora e seu marido é mantida e valorizada, estabelece contigüidade e complementaridade entre suas atitudes, na medida em que é uma relação primeiramente espiritual. Esta ligação é o fundamento da ligação que não se dissolve. O mesmo quadro aparece em outras das legendas mencionadas, como veremos.

As escolhas que o registro legendário feito por Jacopo da Varazze evidenciam aproximam-no dos reformistas romanos mais radicais. O movimento reformista que traduz a "liberdade da Igreja" em termos de "paz da Igreja" pretende disciplinar os núcleos de "violência" e "desordem" representados pelos infiéis e pelos cristãos que agridem aos bens e à autoridade eclesiática, mas também se volta para a domesticidade, aprofundando, ao mesmo tempo em que toca, as dimensões familiares e íntimas da sociedade cristã a ser disciplinada. Inaugura, assim, o universo da sexualidade como gerador de espaço interior e espaço da intimidade, levando a forma social nova que quis inaugurar para o segredo das consciências e corações. 
A relativização da visão da mulher como potencialmente perniciosa também se relativiza no caso de personagens que não são santas. Observando a caracterização dos leigos na obra, podemos afirmar que a tolerância acompanha a obra moralizadora e didática. Os leigos estão duplamente protegidos: pelo casamento e pelo perdão viabilizado pela penitência. Ao lado das pecadoras, aparece um grupo importante de mulheres que - embora não sendo santas - em nada parecem desaprovadas por Jacopo da Varazze. São as mulheres casadas que já se tornaram mães. Essas mulheres, diferentemente das recém-casadas ainda sem filhos e das viúvas jovens também sem filhos - às quais ronda o mal na Legenda Aurea - estavam fora do circuíto das desconfianças públicas acerca do bom uso de sua sexualidade. O matrimônio e a maternidade aprovavam essas mulheres e suas relações carnais, pois atestavam submissão da concupiscência nas mesmas e, de certa forma, garantiam sua indisponibilidade para práticas extraconjugais.

A benevolência para com as mulheres casadas liga-se historicamente àquela dirigida às pecadoras. Embora a ampliação do perdão a essas mulheres também seja acompanhada por um aumento da rejeição às mulheres que fogem aos quadros de transgressão controlados pelo clero, essa flexibilização da hierarquia dos pecados favorece a remissão relativa da imagem feminina associada à luxúria. Observemos que a soberba, a luxúria e a avareza são pecados imputados às santas que são meretrizes penitentes e expõem conjuntamente o ponto mais baixo da condição de pecado das mulheres. A relativização do perfil luxurioso se dá de forma clara no perdão estendido a Teodora. De que maneira essa proposta de perdão ao adultério feminino atingiu a domesticidade, não sabemos. Mas temos conhecimento da eficiência relativa do perdão estendido às prostitutas nos séculos XII e XIII. O subtexto do dominicano Jacopo da Varazze é assim registro de um dos espaços de poder - pouco visível mas capital - em que se deu, se não a vitória completa dos ideais gregorianos mais radicais, ao menos a derrota cultural do monasticismo.

A obtenção do perdão por Teodora difere, de forma importante, daquele obtido pelas demais santas pecadoras. A relação penitencial das meretrizes se reduz a Deus, objeto de suas ofensas e do qual se busca obter o perdão. O pecado de Teodora, no entanto, arrola uma terceira personagem. É essencial em sua legenda o relato do destino do marido, paralelo à sua história de reclusão. $\mathrm{O}$ mesmo acontece nas demais legendas em que existe adultério. Esse pecado sempre diz respeito ao destino - de remissão ou condenação - não apenas daquele que pecou, mas do casal. O perdão e fidelidade do marido tornam-se 
lição de autodomínio daquele que, como "cabeça da esposa", deve ser seu orientador e espelho de seu próprio autodomínio. A Legenda Aurea exige essa fidelidade matrimonial de ambos: marido e esposa. Tal mensagem veiculada à mais difundida coletânea hagiográfica medieval testemunha a atuação da Igreja e, particularmente, das ordens mendicantes no processo de promoção da imagem feminina e dos laços emocionais entre o casal, como veículo de disciplinamento espiritual e social. O perdão e a fidelidade do marido de Teodora e dos esposos de supostas adúlteras aos laços conjugais são os meios através dos quais esses homens expressam seu autodomínio e através dos quais vêm a santificar-se.

Através do adultério, Jacopo da Varazze defende a importância da indissolubilidade do laço matrimonial. Os casos de falso adultério ilustrados pela acusação de Henrique II contra sua esposa inocente evocam a responsabilidade do marido que pode, nesse caso, efetivamente levar a mulher a perder-se. Portanto, o casamento é lugar de aperfeiçoamento, em que cada cônjuge é guardião da saúde espiritual do outro. Esse quadro das relações matrimoniais idealiza o casamento como espaço da felicidade, coincidindo o ápice da espiritualização com o da satisfação pessoal. Nos casos de falso adultério, o clímax da felicidade e da vida religiosa se dá no restabelecimento da unidade do casal. Todavia, a proximidade física não é diretamente relacionada à santidade. $\mathrm{O}$ companheirismo de Herodes e Herodias é proporcional ao seu aprofundamento nas misérias espirituais. Embora o companheirismo deste casal seja tocante, o adultério retira deste consenso de vontades toda legitimidade. Esta pode, única e exclusivamente, ser estabelecida pelo julgamento dos sacerdotes em promover a indissolubilidade do casamento.

Nos casos de adultério que envolvem reis que aparecem na Legenda Aurea, ocorre a dissolução da ligação conjugal, através da divulgação pública do caso e de sua exposição a recursos judiciais tradicionais, redundando, invariavelmente, na repreensão ou condenação divina daquele que cometeu o adultério sem arrependimento, ou daquele que injustamente o presumiu. Aos recursos da lei civil e da violência familiar, a Legenda Aurea propõe a reabilitação da penitência canônica e um igualmente íntimo entendimento doméstico.

A presunção de adultério na vida dos santos difere dos exemplos reais por nunca implicar num rompimento do laço matrimonial, vindo este a se recompor em sua plenitude através da reaproximação física dos esposos, mesmo depois das maiores agruras. Nesses casos, o adultério catalisa o encontro do indivíduo com seu destino de santidade, por meio da fidelidade à ligação matrimonial e 
familiar. Ser receptivo à reunião do casal depois de sua dissolução e das suspeitas de infidelidade significa realizar a vontade de Deus. $\mathrm{O}$ caso de Teodora novamente é exemplar. Apesar da inexistência de filhos naturais de seu casamento, a vida da santa precisa que esse reencontro se realize mesmo depois de sua morte. O laço estabelecido entre homem e mulher pelo sacramento do matrimônio é indissolúvel. Ele faz de Teodora, de seu marido e da criança uma família verdadeira porque fundamentada no espírito.

Um dos alvos visados por Jacopo da Varazze através dos exemplos de adultério por ele selecionados é a crítica ao costume aristocrático de repúdio das esposas e, sobretudo, o uso do adultério como pretexto para tal. No discurso do eclesiástico, o repúdio aparece como a face masculina do adultério. $\mathrm{O}$ dominicano retrata com dureza o repúdio. A rebeldia canônica e a resistência aos limites do casamento cristão fazem do aristocrata que repudia sua esposa, mencionado na legenda dedicada a são Gregório, um adepto da magia e do demonismo, ${ }^{47}$ atributos reservados, na compilação genovesa, apenas aos seres mais perversos. O perfil dos infiéis muçulmanos na Legenda Aurea fundamentase, em boa parte, em práticas matrimoniais permissivas à endogamia, à dissolubilidade das uniões, à poligamia e ao repúdio. O repúdio é fonte de desordem, de injustiça, inimizade e violência, como ilustram as trajetórias de Herodes e Herodias e Marco Antônio e Cleópatra, entre outras. ${ }^{48} \mathrm{O}$ problema do adultério se situa, portanto, simultaneamente neste domínio público da ordem cristã e naquele da ordem interior. No final da Era Gregoriana, sua relevância se revela no quadro mais amplo da definição da comunidade e da interioridade cristãs, então associadas.

Os exemplos apresentados mostram que a cautela do dominicano ao tratar do adultério diz menos respeito ao seu desinteresse pelo tema do que à dificuldade de atingir seu público-alvo prioritário, os homens. Através da violência perniciosa, representada pelo rapto - forma de casamento e aliança forçadas, presente nas histórias de são Juliano, Henrique II e Albuíno -, ou o exercício

\footnotetext{
${ }^{47}$ Curiosamente, como no caso de Teodora, temos novamente a mediação de um agente mágico concorrente ao cristianismo, defendendo ligações carnais consideradas ilícitas pela doutrina da Igreja. De Sancto Gregorio, XLVI, p. 299-300.

${ }^{48}$ Além dos casos mencionados de repúdio, a Legenda Aurea traz um último exemplo que reforça o sentido global até o momento apontado. Trata-se da degeneração das relações de afinidade existentes entre Otávio e Antônio, motivada pela lascívia deste. Para tomar Cleópatra como esposa, Antônio teria repudiado a irmã de Otávio, ocasionando sua reação, de conhecido desfecho trágico. De Sancto Petro ad vincula, CVI, p. 704-705.
} 
indevido do poder e da justiça - lembremos dos exemplos de Henrique II, Otto III, Davi e Teodósio -, os homens induzem ao adultério ou lhe dão foro de verdade, fomentando seu potencial de perturbação social. Impermeáveis aos fundamentos sobrenaturais da paz e da justiça, sobrepõem-se aos mediadores do sagrado e punem sem misericórdia e sem direito legítimo, delitos que deveriam ser tratados pela temperança canônica. $\mathrm{O}$ adultério, pecado da intimidade para os religiosos, deve ser curado na domesticidade sem o recurso à violência. $\mathrm{O}$ pecado do adultério não anda sozinho. $\mathrm{O}$ incesto, o repúdio, a violência, o regicídio, o parricídio, o assassinato em geral, a injustiça, a calúnia, a traição, a usurpação, a tirania, o acompanham como podemos ver nos casos documentados. Seus desdobramentos públicos são consideráveis. A proposta eclesiástica de julgamento espiritual das causas de adultério repercutia simultaneamente no disciplinamento da intimidade e da autoridade laica. Mesmo que resolvidos na domesticidade, os dramas maritais projetam uma concepção pública que ultrapassa os limites da autoridade familiar. Esta resolução respeita princípios gerais divulgados como universais e geridos por especialistas que educam as sensibilidades numa pastoral que se intimiza e tende assim a projetar a subjetividade no domínio público. ${ }^{49}$

$\mathrm{Na}$ legenda de santa Teodora, Jacopo da Varazze defende a reconciliação do casal face ao adultério alegando a igualdade de valor de todas as faltas e a indissolubilidade da ligação matrimonial cuja legalidade, para ele, independe da consumação carnal, de sua interrupção justificada e da geração de filhos. Portanto, nega também o repúdio baseado na esterilidade. As uniões de Teodora, de Eustáquio, do pai de são Clemente e de Juliano com seus cônjuges não é dependente da existência de uma prole. O casal, e não a família, é o fundamento da unidade que é preciso preservar. A extensão do perdão e a aparente indulgência confirmam a inalterabilidade dos laços matrimoniais. Jacopo da Varazze pretende combater o adultério através da promoção de um laço idealizado entre homem e mulher. Laço criado pelo próprio casamento e constituído por uma forte tensão sentimental que alinhava os relatos nos quais famílias e casais - santos ou não - são apresentados. Essa teia sentimental constitui o núcleo sensibilizador do público para sua visão das relações entre os sexos.

\footnotetext{
${ }^{49}$ A respeito das relações entre a subjetividade e o domínio público neste período, ver CHIFFOLEAU, Jacques. 'Ecclesia de occultis non iudicat'? L'Église, le secret et l'occulte du XIIe au XVe siècle. Micrologus, 14, 2005, p. 359-481.
} 
A firmeza da ligação entre os santos e suas esposas e filhos, a despeito da suspeita ou da consumação do adultério, fala aos leigos sobre a penitência e o perdão disponíveis aos pecadores, mas também da importância do casamento e da existência de um fundamento espiritual para o mesmo. Esse fundamento o torna fonte de santidade. Nos casos apresentados, o adultério acarreta a desagregação do casal. Contudo, a conclusão de cada relato diz para os leigos que a definitiva dissolução dos laços que unem o casal é impossível. Recobrindo de sentimentos essa união, que não é necessariamente física - mas que efetivamente o é para a maioria dos leigos -, o discurso de Jacopo da Varazze aponta para o sexo um lugar sob a esfera do sagrado, enraizando as relações sociais e sobrenaturais envolvidas, na deliberação íntima e secreta de homens e mulheres.

O sucesso da Legenda Aurea ${ }^{50}$ não pode ser tomado como prova do acolhimento de suas considerações a respeito do adultério. A despeito dos testemunhos de sua ampla circulação, não é possível estabelecer os critérios de leitura da obra. Mencionamos as dificuldades sociais para a adoção da perspectiva radical de Jacopo da Varazze. Por hora, é possível notar, que a reforma da Igreja abriu este domínio das práticas e concepções laicas à discussão, bem como os paradigmas monásticos e sua recusa do sexo. O modelo da legenda de santa Teodora para o adultério encontra-se isolado na Legenda Aurea, embora, como tentamos mostrar, esteja ligado de forma coerente às reflexões sobre o casamento que veicula. As legendas aqui apresentadas advogam a estrita indissolubilidade do casamento e a compatibilidade entre o sexo e a santidade em seus domínios. A tensão espiritual que, juntamente com o consentimento e o sexo, constitui o casal substitui a família como garantia da solidez do casamento. A partir do controle dos termos dessa ligação emocional se estabelece um dos fundamentos de uma ordem social que refunda o espaço público na afetividade.

Recebido: março/2007 - Aprovado: setembro/2008

\footnotetext{
${ }^{50}$ Chegaram até nós mais de mil manuscritos da obra. Número verdadeiramente notável para os registros do período que testemunha a amplitude de sua circulação. Estes manuscritos aparecem escritos em latim, mas também numa variedade significativa de línguas vernáculas, o que aponta para a diversificação de seus ambientes de leitura que, desde o último quartel do século XIII, atinge a domesticidade dos laicos letrados. DUNN-LARDEAU, Brenda (dir.). Prefácio, em idem. Legenda aurea: sept siècles de diffusion. Montréal-Paris: Bellarmin-Vrin, 1986, p. 14.
} 